tion with size of these particles have been found to be the same at the various stations.

The principal collecting sites were the Smithsonian Astrophysical Ubservatory's Table Mountain Station above the Mojave Desert of California, a field site of the Geophysical Institute in central Alaska, and the Meteorological Observing Station of the Canadian Meteorological Service at Resolute, North-West Territory, on Cornwallis Island in the Arctic. The collections, begun on July 1, 1955, and completed on June 30, 1956, involved exposing adhesive-covered glass slides to the atmosphere for periods of $24 \mathrm{hr}$., weather permitting. These slides were scanned under a magnification of 500, making possible identification of particles greater than 3 microns in diameter. 'Those suspected to be meteoritic were counted and measured after identification by means of tests designed to distinguish them from other types of dust present, involving the use of back lighting, side lighting and polarized light.

The average rate of fall for each station was $1 \cdot 1$ spherules greater than 3 microns in diameter per sq. cm. per day. Assuming that the density of the counted particles is that of iron, this rate corresponds to an annual accretion for the entire Earth of about $10^{9} \mathrm{kgm}$. of these particles.

These results are of interest in relation to the work of 'Thomsen' and of Buddhue', who have studied spheres of greater abundance and larger size. No particles of the type they describe were found in the collections from the three principal stations of this programme. Uther investigators, notably Crozier ${ }^{3}$ and Kizilirmak ${ }^{4}$, have studied the magnetic components of dust in the air at their respective institutions.

A promising beginning has been made with an analysis of individual particles by X-ray diffraction techniques. The results of this work will be included in a comprehensive report to be submitted to Geochimica et Cosmochimica Acta. A subvention of this project by the Office of Naval Research and the co-operation of the Directors of the collecting stations are gratefully acknowledged.

Paul W. Hodge

Yale University Observatory, New Haven, Connecticut. Aug. 31.

"Thomsen, W. J., Sky and Telescope, 12, 147 (1953).

"Burdihue, J. D., "Mateoritic Dust" (University of New Mexico Press).

${ }^{3}$ Crozier. W. D., New Mexico Institute of Mining and Technology (personal communication, 1956).

+ Kizilirmak, Abdullah, Comm. Faculté d'Ankara, 6, Séri A-Fasc. 2, 186 (1954).

\section{Dried Breadfruit}

IN many of the Pacific territories breadfruit (Artocarpus altilis Forst.) constitutes a staple part of the diet. Excepting fermentation procedures, no means of preserving this food in the Pacific islands have previously been described. It has recently been reported $^{1}$ that the people of the Reef Islands in the British Solomon Islands Protectorate dry breadfruit for use when it is out of season. It is used also as an item of trade with some of the nearby islands.

The method used for drying is to cook the fresh ripe fruit in the ashes of a fire for an hour. The cooked product is left for a day and then it is peeled, the seeds removed, and it is cut into small pieces which are arranged on a net to a depth of four or five inches. This net is suspended over a smokeless fire and the pieces are turned continuously for about six hours.

The dried breadfruit may be kept for twelve months or more if it is stored in coconut baskets on racks above the kitchen fireplace.

A sample of the dried breadfruit was sent to this laboratory. 'The composition of the product is given in Table 1 together with results obtained for fresh breadfruit from Western Samoa. It is noted that the calcium content of the dried breadfruit is much higher than would be expected from tho fresh breadfruit figure. This may be due to contamination of the product by coral dust during preparation.

$\begin{array}{lcc} & \text { Table } 1 & \\ & \begin{array}{c}\text { Dried } \\ \text { (per cent) }\end{array} & \begin{array}{c}\text { Frest } \\ \text { (per cent) }\end{array} \\ \text { Water } & 8 \cdot 0 & 50 \cdot 0 \\ \text { Ether extract } & 2 \cdot 1 & 0.5 \\ \text { Crude fibre } & 4 \cdot 7 & 1 \cdot 2 \\ \text { Total nitrogen } & 0.68 & 0.12 \\ \text { Asli } & 4 \cdot 2 & 0.5 \\ \text { Starch (acid hydrolysis) } & 72.0 & 12.0 \\ \text { Calcium } & 0.44 & 0.03 \\ \text { Pnosphorus } & 0.13 & 0.03\end{array}$

We wish to thank Mr. J. L. O. Tedder, District Commissioner, Eastern District, British Solomon Islands Protectorate, for supplying us with a sample of dried breadfruit for analysis.

F. E. Peters

Pamela A. Wizls

South Pacific Commission, Noumea,

New Caledonia. Sept. 20 .

1 Tedder, J. L. O., South Pacific Comm. Quart. Bull., 6, No. 3, 21 (1956).

\section{"Fluorimetry"}

IN a recent communication to $N^{\top}$ ature $e^{1}$ there appears an article entitled "Determination of Intermediary Metabolites by Enzymic Fluorimetry". May I suggest that the term fluorimetry is quite inappropriate in the sense in which it is employed in the article, namely, that of the measurement of fuorescent light.

As the words 'fluor-spar' and 'hydrofluoric' show, fluor is well established as an abbreviation of fuorine. Surely, then, fluorimetry, in a chemical context, can scarcely be interpreted otherwise than as meaning assay of fuorine, not the measurement of flurescence.

It would seem unfortunate if the usage here called in question were followed by others; it would certainly be most confusing to foreign workers.

In the absence of a suitable single word for the measurement of the intensity of fluorescent light, the determinations referred to in the article would seem properly to be described as 'by fluorescence measurement' or 'by fluorescence estimation'-longer though thoso are. Brevity may be bought too dearly.

\section{Berkeley Place,}

\section{H. BIACKMAN}

$$
\text { Sept. } 25 .
$$

${ }^{1}$ Greengard, P., Nature, 178, 632 (1956). 